\title{
Protokół \\ z przebiegu Walnego Zgromadzenia Delegatów Sprawozdawczo-Wyborczego w Warszawie z dnia 12.02.2016 r.
}

I. Prof. B. Markiewicz, z-czyni przewodniczącego PTF dokonała uroczystego otwarcia Wlanego Zgromadzenia Delegatów PTF.

II. Prof. B. Markiewicz odczytała wspomnienia o zmarłych w 2015 r. członkach PTF. Delegaci uczcili pamięć o zmarłych minutą ciszy.

III. Prof. B. Markiewicz zaproponowała, aby przewodniczącym Walnego Zgromadzenia Delegatów został dr hab. M. Rembierz. Zgromadzeni jednomyślnie poparli tę kandydaturę. Następnie dr hab. M. Rembierz zaproponował, aby Walne Zgromadzenie Delegatów było protokołowane przez dr M. Gawin. Kandydatura ta została jednomyślnie zaakceptowana przez zebranych.

IV. Przy jednomyślnej zgodzie Delegatów uchwalono porządek obrad.

V. Przewodniczący Walnego Zgromadzenia uznał, że na sali obecne jest kworum, bowiem na Sali obecnych jest 38 osób z 64 uprawnionych do głosowania.

VI. Zgromadzeni jednomyślnie przyjęli protokół z poprzedniego Walnego Zgromadzenia Delegatów PTF. (Uchwała nr 1/2016 w sprawie przyjęcia protokołu z poprzedniego Walnego Zgromadzenia Delegatów).

VII. Prof. B. Markiewicz przedstawiła sprawozdanie z działalności ZG PTF w roku 2015. Następnie dr M. Gawin, sekretarz PTF, przedstawiła sprawozdanie merytoryczne z działalności PTF w roku 2015. 
VIII. Prof. B. Markiewicz w zastępstwie skarbnika, prof. J. Stuchlińskiego, przedstawiła sprawozdanie finansowe z działalności PTF, zaznaczając, że księgowość PTF prowadzi profesjonalna firma zewnętrzna.

IX. Przewodniczący Głównej Komisji Rewizyjnej, dr hab. M. Kubiak przedstawił sprawozdanie oraz wniosek o udzielenie absolutorium ZG PTF. Przedstawił także prośbę o terminowe wysyłanie sprawozdań.

X. Odbyła się krótka dyskusja nad sprawozdaniami. Zabrał głos mgr K. Czarnota zwracając uwagę, że sprawozdania dotyczyły także Olimpiady.

XI. Następnie odbyły się głosowania nad przyjęciem sprawozdań. Sprawozdanie merytoryczne zostało przyjęte jednomyślnie. (Uchwała nr 2/2016)

Sprawozdanie finansowe zostało przyjęte jednomyślnie. (Uchwała nr 3/2016)

Sprawozdanie Głównej Komisji Rewizyjnej zostało przyjęte jednomyślnie.

Również jednomyślnie zostało udzielone absolutorium ZG PTF. (Uchwała $\mathrm{nr}$ 4/2016)

XII. Wybrano członków komisji skrutacyjnej, w skład której weszli: dr K. Michalski, dr G. Dominiak, mgr C. Głogowska. Wszyscy członkowie komisji zostali wybrani jednomyślnie.

XIII. Prof. B. Markiewicz zaproponowała, aby Przewodniczącym PTF pozostał prof. W. Stróżewski. Nie zgłoszono innych kandydatur.

Odbyło się głosowanie. Prof. Stróżewski został Przewodniczącym PTF przy 35 głosach wspierających jego kandydaturę, 1 głosie przeciw i 1 głosie nieważnym. (Uchwała nr 5/2016)

XIV. Wybór członków ZG PTF

Do wyborów do ZG PTF zgłoszono:

prof. B. Markiewicz, prof. J. Stuchlińskiego, dr M. Gawin, prof. R. Kleszcza, dr hab. M. Rembierza, prof. K. Brzechczyna, dr hab. M. Zdrenkę, mgr L. Garcarza.

Ponadto prof. B. Markiewicz zgłosiła kandydaturę prof. P. Łukowa oraz dr hab. S. Kołodziejczyka do ZG PTF.

Zgłoszono także kandydaturę prof. R. Piekarczyka oraz prof. M. Siwca, przy czym prof. R. Piekarski nie zgodził się kandydować.

Prof. B. Markiewicz podniosła wniosek o zamknięcie listy kandydatów do ZG PTF. 
Odbyło się głosowanie, w wyniku którego wybrano następujący skład ZG PTF:

członek ZG - prof. B. Markiewicz (29 głosów),

członek ZG - prof. J. Stuchliński (29 głosów),

członek ZG - dr M. Gawin (34 głosy),

członek ZG - prof. R. Kleszcz (34 głosy),

członek ZG - prof. M. Rembierz (34 głosy),

członek ZG - prof. K. Brzechczyn (28 głosów),

Z-ca członka ZG - dr hab. M. Zdrenka (26 głosów),

z-ca członka ZG - prof. P. Łuków (27 głosów),

z-ca członka ZG - dr hab. S. Kołodziejczyk (21 głosów).

(Uchwała nr 6/2016)

XV. Wybór członków Głównej Komisji Rewizyjnej

Zgłoszono następujących kandydatów na członków Głównej Komisji Rewizyjnej: dr hab. M. Kubiak, prof. A. Łukasik, dr M. Baranowska, dr M. Woroniecki, mgr K. Czarnota.

Wynik głosowania był następujący:

członek - dr hab. M. Kubiak (35 głosów),

członek - prof. A. Łukasik (36 głosów),

dr M. Baranowska (34 głosy),

dr M. Woroniecki (34 głosy),

z-ca członka - mgr K. Czarnota (33 głosy).

Ponieważ dwoje kandydatów uzyskało taką samą liczbę głosów, delegaci jednomyślnie uznali, wybrani do Głównej Komisji Rewizyjnej w trakcie zebrania konstytuującego Główną Komisję Rewizyjną ustala, która z wybranych osób będzie pełniła funkcję członka, a która zastępcy członka.

(Uchwała nr 7/2016)

XVI. Wybór członków Sądu Koleżeńskiego

Zgłoszono następujących kandydatów do Sądu Koleżeńskiego: dr K. Wrzesiński, prof. W. Wójcik, prof. R. Piekarski, dr Z. Zalewski, prof. E. Zgolińska, dr M. Woźniczka, mgr L. Garcarz, dr hab. R. Mordarski.

Wynik głosowania był następujący:

członek - dr K. Wrzesiński (33 głosy),

członek - prof. W. Wójcik (31 głosów),

członek - prof. R. Piekarski (31 głosów),

członek - dr Z. Zalewski (28 głosów),

członek - dr M. Woźniczka (32 głosy),

z-ca członka - prof. E. Zgolińska (27 głosów),

z-ca członka - dr hab. R. Mordarski (24 głosy).

(Uchwała nr 8/2016) 


\section{Przerwa na ukonstytuowanie się ZG PTF}

\section{XVII.}

Po przerwie członkowie ZG PTF poinformowali Delegatów o przyznanych funkcjach w ZG PTF: prof. B. Markiewicz została wybrana z-czynią przewodniczącego, prof. J. Stuchliński został wybrany skarbnikiem, dr M. Gawin został wybrana sekretarzem.

\section{Uchwalenie zmian w Statucie}

Następnie Przewodniczący Walnego Zgromadzenia Delegatów zaproponował dokonanie niezbędnych zmian Statutu PTF.

Dr K. Wrzesiński przedstawił propozycję zmian Statutu wynikających z konieczności dostosowania Statutu PTF do zmian ustawy „Prawo o stowarzyszeniach" dokonanego ustawą z dnia 25 września 2015r. (Dz. U. z 2015r., poz. 1923) oraz innych zmian w obowiązującym prawie oraz wprowadzenia zmian wynikających $\mathrm{z}$ aktualnych potrzeb organizacyjnych Towarzystwa. W związku z powyższym Przewodniczący Walnego Zgromadzenia Delegatów przedstawił i poddał pod głosowanie następujące propozycje zmian Statutu, aby:

\section{1) dokonać zmiany treści $\$ 3$ poprzez dodanie po wyrazie "Siedzi-} ba" wyrażenia "władz naczelnych" w taki sposób, iż § 3 uzyskuje brzmienie:

\section{„Siedzibą władz naczelnych Towarzystwa jest m.st. Warszawa."}

Za przyjęciem zmiany w głosowaniu jawnym oddano 37 głosów, przeciwko 0 głosów, wstrzymało się 0 członków.

W związku z powyższym Przewodniczący Walnego Zgromadzenia Delegatów PTF stwierdził, iż proponowana zmiana Statutu została przyjęta.

\section{2) dokonać zmiany treści $§ 5$ w taki sposób, iż $§ 5$ uzyskuje brzmienie:}

„Towarzystwo ma prawo zakładać terenowe jednostki organizacyjne - oddziały Polskiego Towarzystwa Filozoficznego - nieposiadające osobowości prawnej".

Za przyjęciem zmiany w głosowaniu jawnym oddano 37 głosów, przeciwko 0 głosów, wstrzymało się 0 członków. 
W związku z powyższym Przewodniczący Walnego Zgromadzenia Delegatów PTF stwierdził, iż proponowana zmiana Statutu została przyjęta.

3) dokonać zmiany treści $\$ 6 \mathrm{w}$ taki sposób, iż § 6 uzyskuje brzmienie:

„Towarzystwo używa pieczęci z napisem „Polskie Towarzystwo Filozoficzne" a w odniesieniu do oddziału „Polskie Towarzystwo Filozoficzne - Oddział w ........", lub „Oddział ........ - Polskiego Towarzystwa Filozoficznego"."

Za przyjęciem zmiany w głosowaniu jawnym oddano 37 głosów, przeciwko 0 głosów, wstrzymało się 0 członków.

W związku z powyższym Przewodniczący Walnego Zgromadzenia Delegatów PTF stwierdził, iż proponowana zmiana Statutu została przyjęta.

4) dokonać zmiany tytułu rozdziału 2. Statutu w taki sposób, iż tytuł rozdziału 2. Statutu uzyskuje brzmienie:

\section{„2. CELE I ZADANIA TOWARZYSTWA”}

Za przyjęciem zmiany w głosowaniu jawnym oddano 37 głosów, przeciwko 0 głosów, wstrzymało się 0 członków.

W związku z powyższym Przewodniczący Walnego Zgromadzenia Delegatów PTF stwierdził, iż proponowana zmiana Statutu została przyjęta.

5) dokonać zmiany treści $\$ 7 \mathrm{w}$ taki sposób, iż dotychczasowa treść zostaje oznaczona jako ustęp „1." oraz dodaje się ustępy 2, 3 i 4 wskutek czego § 7 uzyskuje brzmienie:

„1. Celem Towarzystwa jest uprawianie i krzewienie nauk filozoficznych.

2. W zakresie swoich celów statutowych Towarzystwo może reprezentować interesy zbiorowe swoich członków wobec organów władzy publicznej.

3. Towarzystwo może należeć do zagranicznych i międzynarodowych organizacji i stowarzyszeń mających za przedmiot i cel działalności uprawianie i krzewienie nauk filozoficznych, jeżeli nie na- 
rusza to zobowiązań wynikających z umów międzynarodowych, których Rzeczpospolita Polska jest stroną.

4. O przystąpieniu do organizacji lub stowarzyszeń, o których mowa w ust. 3 bądź o wystąpieniu z nich decyduje Zarząd Główny zwykłą większością głosów."

Za przyjęciem zmiany w głosowaniu jawnym oddano 37 głosów, przeciwko 0 głosów, wstrzymało się 0 członków.

W związku z powyższym Przewodniczący Walnego Zgromadzenia Delegatów PTF stwierdził, iż proponowana zmiana Statutu została przyjęta.

6) dokonać zmiany treści § 8 w taki sposób, iż dotychczasowa treść zostaje oznaczona jako ustep „1." oraz dodaje się usteppy 2,3 i 4 wskutek czego $\$ 8$ uzyskuje brzmienie:

„1. Towarzystwo realizuje swoje zadania przez:

a) prowadzenie wykładów naukowych i popularnonaukowych,

b) odbywanie zebrań naukowo-dyskusyjnych,

c) organizowanie zjazdów naukowych,

d) prowadzenie bibliotek dzieł filozoficznych oraz dzieł pomocnych przy studiowaniu nauk filozoficznych,

e) działalność wydawnicza,

f) reprezentowanie potrzeb nauk filozoficznych wobec władz i społeczeństwa,

g) udział w pracach instytucji międzynarodowych, służących uprawianiu i krzewieniu nauk filozoficznych.

2. Towarzystwo posiada księgozbiór, składający się m. in. z biblioteki prof. Kazimierza Twardowskiego udostępniany w ramach „Połączonych Bibliotek Wydziału Filozofii i Socjologii UW, Instytutu Filozofii i Socjologii PAN oraz Polskiego Towarzystwa Filozoficznego".

3. Towarzystwo prowadzi olimpiady filozoficzne i konkursy filozoficzne w celu krzewienie wiedzy filozoficznej wśród młodzie$\dot{\mathbf{z} y}$.

4. Towarzystwo posiada odznakę członkowską na podstawie obowiązujących w tym zakresie przepisów, której wzór stanowi załącznik nr 1 do niniejszego Statutu.

Za przyjęciem zmiany w głosowaniu jawnym oddano 37 głosów, przeciwko 0 głosów, wstrzymało się 0 członków. 
W związku z powyższym Przewodniczący Walnego Zgromadzenia Delegatów PTF stwierdził, iż proponowana zmiana Statutu została przyjęta.

\section{7) dokonać zmiany treści §9 $\mathrm{w}$ taki sposób, iż po dotychczasowej treści} przepisu dodaje się zdanie drugie, tak iż § 9 uzyskuje brzmienie:

„Działalność Towarzystwa opiera się na pracy społecznej ogółu jej członków. Do prowadzenia swych spraw Towarzystwo może zatrudniać pracowników, w tym swoich członków".

Za przyjęciem zmiany w głosowaniu jawnym oddano 37 głosów, przeciwko 0 głosów, wstrzymało się 0 członków.

W związku z powyższym Przewodniczący Walnego Zgromadzenia Delegatów PTF stwierdził, iż proponowana zmiana Statutu została przyjęta.

8) dokonać zmiany treści § $10 \mathrm{w}$ taki sposób, iż zdanie pierwsze oznacza sie jako ustep „1.", zdanie drugie jako ustep „2.", w ust. 1 dodaje się pkt. "c) o treści „wspierajacych” w ust. 2 dodaje się po wyrazie "lub" wyraz „inne” oraz dodaje się ustępy 3 i 4, tak iż $\$ 10$ uzyskuje brzmienie:

„1. Członkowie Towarzystwa dzielą się na:
a) zwyczajnych,
b) honorowych;
c) wspierających.

2. Członkiem zwyczajnym Towarzystwa może być każda pełnoletnia osoba, która ma ukończone studia filozoficzne lub inne kwalifikacje uznane przez Zarząd Główny Towarzystwa za równorzędne.

3. Cudzoziemcy mogą wstępować do Towarzystwa na warunkach właściwych dla obywateli polskich.

4. Osoba prawna może być jedynie wspierającym członkiem Towarzystwa".

Za przyjęciem zmiany w głosowaniu jawnym oddano 37 głosów, przeciwko 0 głosów, wstrzymało się 0 członków.

W związku z powyższym Przewodniczący Walnego Zgromadzenia Delegatów PTF stwierdził, iż proponowana zmiana Statutu została przyjęta. 
9) dokonać zmiany treści § $13 \mathrm{w}$ taki sposób, iż po dotychczasowej treści przepisu zamiast kropki stawia się przecinek i dodaje wyrażenie „z zastrzeżeniem § 9 Statutu.", tak iż § 13 uzyskuje brzmienie:

\section{"Członkowie Towarzystwa pełnią funkcje honorowo, z zastrzeże- niem $\S 9$ Statutu".}

Za przyjęciem zmiany w głosowaniu jawnym oddano 37 głosów, przeciwko 0 głosów, wstrzymało się 0 członków.

W związku z powyższym Przewodniczący Walnego Zgromadzenia Delegatów PTF stwierdził, iż proponowana zmiana Statutu została przyjęta.

10) dokonać zmiany treści § 14 w taki sposób, iż dotychczasowa treść zostaje oznaczona jako ustep "1." oraz dodaje sie ustepy 2,3 i 4 wskutek czego § 14 uzyskuje brzmienie:

„1. Każdy członek zwyczajny ma obowiązek:

a) przestrzegać postanowień statutu Towarzystwa oraz uchwał i zarządzeń władz Towarzystwa,

b) przyczyniać się do realizacji celów i zadań Towarzystwa,

c) wpłacać regularnie składkę roczna, przy czym w wyjątkowych przypadkach członek Towarzystwa może być zwolniony z obowiązku płacenia składek uchwałą Zarządu Głównego podjętą na wniosek Zarządu Oddziału.

2. Członkiem wspierającym może być osoba fizyczna lub prawna zainteresowana działalnością Towarzystwa, która zadeklaruje poparcie finansowe lub inną pomoc materialną na rzecz Towarzystwa. Członkostwo wspierające nabywa się w drodze uchwały Zarządu Głównego Towarzystwa przyjętej w następstwie złożenia deklaracji przez kandydata na członka wspierającego.

3. Formę i rodzaj wspierania Towarzystwa członkowie wspierający ustalają z Zarządem Głównym Towarzystwa.

4. Członek wspierający ma prawo do:

a) wspierania Towarzystwa finansowo lub materialnie.

b) uczestnictwa w posiedzeniach szkoleniowych i naukowych organizowanych przez Towarzystwo.

c) uczestniczenia w Walnym Zgromadzeniu Delegatów oraz w Walnym Zebraniu Oddziału z głosem doradczym.

5. Członek wspierający jest zobowiązany do wywiązywania się z deklarowanych świadczeń. 


\section{Osoba prawna działa $\mathrm{w}$ Towarzystwie przez swoich przedsta- wicieli".}

Za przyjęciem zmiany w głosowaniu jawnym oddano 37 głosów, przeciwko 0 głosów, wstrzymało się 0 członków.

W związku z powyższym Przewodniczący Walnego Zgromadzenia Delegatów PTF stwierdził, iż proponowana zmiana Statutu została przyjęta.

11) dokonać zmiany treści § $15 \mathrm{w}$ taki sposób, iż dotychczasowa treść zostaje oznaczona jako ustẹp "1.", wyrażenie "niż rok” w ust. 1 lit b) zastẹpuje się wyrażeniem "dwa lata", dodaje się w ust. 1 lit. "c" oraz dodaje sie ustep 2., wskutek czego $\$ 15$ uzyskuje brzmienie:

„1. Członkiem Towarzystwa przestaje być ten, kto:

a) pisemnie zawiadomi Zarząd Główny o swoim wystąpieniu,

b) zostanie skreślony z listy członków przez Zarząd Główny z powodu nie wywiązywania się z obowiązków członkowskich w tym nie płacenia składek członkowskich dłużej niż dwa lata, mimo pisemnego upomnienia;

c) zostanie wykluczony z Towarzystwa na mocy decyzji Zarządu Głównego PTF podjętej wskutek wyroku Sądu Koleżeńskiego PTF orzekającego zawinione przez członka PTF naruszenie postanowień Statutu PTF i wnoszącego o wykluczenie członka z Towarzystwa.

2. Członek skreślony lub wykluczony winien otrzymać na piśmie decyzję Zarządu Głównego wskazującą powody skreślenia (wykluczenia) wraz z uzasadnieniem, od której członkowi przysługuje prawo wniesienia na piśmie odwołania, w terminie $30 \mathrm{dni}$ od otrzymania decyzji, do najbliższego Walnego Zgromadzenia Delegatów PTF. Do chwili rozpatrzenia odwołania lub bezskutecznego upływu terminu do wniesienia odwołania, decyzja Zarządu Głównego PTF o skreśleniu (wykluczeniu) jest nieprawomocna. Walne Zgromadzenie Delegatów PTF rozpatruje sprawę odwołania na najbliższym posiedzeniu. Członek skreślony (wykluczony) winien mieć możliwość obecności na tej części Walnego Zgromadzenia Delegatów PTF, która będzie poświęcona rozpatrzeniu odwołania".

Za przyjęciem zmiany w głosowaniu jawnym oddano 37 głosów, przeciwko 0 głosów, wstrzymało się 0 członków. 
W związku z powyższym Przewodniczący Walnego Zgromadzenia Delegatów PTF stwierdził, iż proponowana zmiana Statutu została przyjęta.

12) dokonać zmiany oznaczeń obu cześci § 16 w taki sposób, iż oznaczenia literowe " $a{ }^{\prime \prime}, ~ " b "$, zasteppuje się oznaczeniem za pomoca cyfr "1." i „2.", wskutek czego § 16 uzyskuje brzmienie:

„1. Za szczególne zasługi dla filozofii polskiej lub wyróżniającą się działalność na rzecz Towarzystwa, na wniosek Zarządu Głównego, Walne Zgromadzenie może nadać godność członka honorowego.

2. Członkowie honorowi posiadają prawa członków zwyczajnych, lecz są zwolnieni z obowiązku płacenia składek".

Za przyjęciem zmiany w głosowaniu jawnym oddano 37 głosów, przeciwko 0 głosów, wstrzymało się 0 członków.

W związku z powyższym Przewodniczący Walnego Zgromadzenia Delegatów PTF stwierdził, iż proponowana zmiana Statutu została przyjęta.

13) dokonać zmiany treści § 17 w taki sposób, iż zdanie pierwsze oznacza sie jako ustep „1.", zdanie drugie jako ustep „2.", oraz dodaje sie ustep 3 , tak iż $\$ 17$ uzyskuje brzmienie:

„1. Władzami naczelnymi Towarzystwa są:
a) Walne Zgromadzenia Delegatów,
b) Zarząd Główny,
c) Główna Komisja Rewizyjna,
d) Sąd Koleżeński.

2. Uchwały władz wybieralnych zapadają zwykłą większością głosów przy obecności co najmniej połowy członków tych władz, przy głosach wyrównanych rozstrzyga głos Przewodniczącego.

3. W umowach między Towarzystwem a członkiem Zarządu Głównego lub członkiem Zarządu Oddziału oraz w sporach z Towarzystwem, Towarzystwo reprezentuje członek Głównej Komisji Rewizyjnej wskazany w uchwale tego organu lub pełnomocnik powołany uchwałą Walnego Zebrania Delegatów".

Za przyjęciem zmiany w głosowaniu jawnym oddano 37 głosów, przeciwko 0 głosów, wstrzymało się 0 członków. 
W związku z powyższym Przewodniczący Walnego Zgromadzenia Delegatów PTF stwierdził, iż proponowana zmiana Statutu została przyjęta.

14) dokonać zmiany treści $\$ 18$ w taki sposób, iż zdanie pierwsze oznacza sie jako ustepp „1.”, zdanie drugie jako ustęp „2." oraz w ust. 1 po wyrazie "Zgromadzeniu” dodaje się wyraz "Delegatów”, a po wyrazie „uczestnicza” dodaje sie wyrażenie "z prawem głosowania” a także zmienia się treść pkt b) w ust. 1, tak, iż § 18 uzyskuje brzmienie:

„1. W Walnym Zgromadzeniu Delegatów uczestniczą z prawem głosowania:

a) delegaci Oddziałów Towarzystwa w liczbie 3 z każdego Oddziału, a nadto jeśli Oddział liczy ponad 100 członków, po jednym z każdej dalszej rozpoczętej setki członków Oddziału,

b) członkowie Zarządu Głównego, Głównej Komisji Rewizyjnej, Sądu Koleżeńskiego.

2. Każdy członek Towarzystwa, nie będący delegatem może brać udział w Walnym Zgromadzeniu, jednak bez prawa głosowania".

Za przyjęciem zmiany w głosowaniu jawnym oddano 37 głosów, przeciwko 0 głosów, wstrzymało się 0 członków.

W związku z powyższym Przewodniczący Walnego Zgromadzenia Delegatów PTF stwierdził, iż proponowana zmiana Statutu została przyjęta.

15) dokonać zmiany oznaczeń obu części § 19 w taki sposób, iż oznaczenia literowe "a $a^{\prime \prime}, b^{\prime \prime}$, zastepuje sie oznaczeniem za pomoca cyfr „1." $i$ „2.", wskutek czego § 19 uzyskuje brzmienie:

„1. Walne Zgromadzenie sprawozdawcze odbywa się co najmniej raz na rok, a sprawozdawczo-wyborcze raz na cztery lata. Zarząd Główny zwołuje Walne Zgromadzenie przesyłając Zarządom oraz Delegatom Oddziałów zawiadomienie o dacie, miejscu i porządku obrad najpóźniej na dwa tygodnie przed terminem.

2. Nadzwyczajne Walne Zgromadzenie może zostać zwołane z inicjatywy Zarządu Głównego, Głównej Komisji Rewizyjnej a także na pisemnie zgłoszone żądanie co najmniej trzech Oddziałów, uchwalone przez ich Walne Zebranie. Zarząd Główny obowiązany jest do zwołania $\mathrm{w}$ ciągu miesiąca od wpłynięcia wniosku nadzwyczajnego Walnego Zgromadzenia z zachowaniem tego samego trybu zwoływania, jak przy zwyczajnym Walnym Zgromadzeniu". 
Za przyjęciem zmiany w głosowaniu jawnym oddano 37 głosów, przeciwko 0 głosów, wstrzymało się 0 członków.

W związku z powyższym Przewodniczący Walnego Zgromadzenia Delegatów PTF stwierdził, iż proponowana zmiana Statutu została przyjęta.

16) dokonać zmiany treści § $20 \mathrm{w}$ taki sposób, iż po wyrażeniu „Walne Zgromadzenie” dodaje się wyraz „Delegatów” oraz w pkt. h) usuwa się wyrażenie "W przypadku ustalenia warunków statutowych dla ich utworzenia”, wskutek czego „\$20 uzyskuje brzmienie:

„Walne Zgromadzenie Delegatów :

a) podejmuje uchwały co do kierunków działalności Towarzystwa,

b) zatwierdza sprawozdania Zarządu Głównego i Głównej Komisji Rewizyjnej oraz udziela absolutorium Zarządowi Głównemu,

c) dokonuje wyboru na okres czterech lat przewodniczącego i pozostałych członków Zarządu Głównego, oraz zastępców członków Zarządu Głównego,

d) dokonuje wyboru na okres czterech lat Głównej Komisji Rewizyjnej oraz Zastępców członków,

e) dokonuje wyboru na okres czterech lat członków Sądu Koleżeńskiego oraz Zastępców członków,

f) ustala wysokość składek członkowskich,

g) rozstrzyga sprawy poddane pod jego obrady przez Zarząd Główny lub na pisemny wniosek co najmniej 5 członków Towarzystwa, złożony na miesiąc przed terminem Walnego Zgromadzenia,

h) podejmuje uchwały o utworzeniu Oddziałów Towarzystwa lub ich likwidacji,

i) z własnej inicjatywy lub na wniosek zarządu Głównego uchwala zmiany statutu lub rozwiązanie Towarzystwa, jeśli uchwały takie zostały przewidziane $\mathrm{w}$ rozesłanym porządku obrad,

j) rozstrzyga o przeznaczeniu majątku Towarzystwa, w razie jego rozwiązania".

Za przyjęciem zmiany w głosowaniu jawnym oddano 37 głosów, przeciwko 0 głosów, wstrzymało się 0 członków.

W związku z powyższym Przewodniczący Walnego Zgromadzenia Delegatów PTF stwierdził, iż proponowana zmiana Statutu została przyjęta. 


\section{7) dokonać zmiany treści § 23 poprzez dodanie po pkt. f) pkt g), w brzmieniu:}

„g) sprawuje pieczę nad księgozbiorem Towarzystwa udostępnianym w ramach „Połączonych Bibliotek Wydziału Filozofii i Socjologii UW, Instytutu Filozofii i Socjologii PAN oraz Polskiego Towarzystwa Filozoficznego" oraz dokonuje wszelkich niezbędnych czynności faktycznych i prawnych dotyczących tego księgozbioru".

Za przyjęciem zmiany w głosowaniu jawnym oddano 37 głosów, przeciwko 0 głosów, wstrzymało się 0 członków.

W związku z powyższym Przewodniczący Walnego Zgromadzenia Delegatów PTF stwierdził, iż proponowana zmiana Statutu została przyjęta.

18) dokonać zmiany § 24 poprzez nadaniu mu nowej treści:

„1. Oświadczenia woli w imieniu Towarzystwa składają: Przewodniczący Zarządu Głównego - samodzielnie, zastępca Przewodniczącego Zarządu Głównego łącznie z dowolnym członkiem Zarządu.

2. Oświadczenia woli w zakresie zobowiązań majątkowych w imieniu Towarzystwa składa Przewodniczący Zarządu Głównego łącznie ze skarbnikiem lub zastępca Przewodniczącego Zarządu Głównego łącznie ze skarbnikiem".

Za przyjęciem zmiany w głosowaniu jawnym oddano 37 głosów, przeciwko 0 głosów, wstrzymało się 0 członków.

W związku z powyższym Przewodniczący Walnego Zgromadzenia Delegatów PTF stwierdził, iż proponowana zmiana Statutu została przyjęta.

19) dokonać zmiany $\$ 27$ w taki sposób, iż dotychczasową treść oznacza sie jako ustep "1." oraz dodaje się ustepp 2 , tak iż $\$ 27$ uzyskuje brzmienie:

„1. Główna Komisja Rewizyjna składa się z trzech członków i 2-ch zastępców (odpowiednio stosuje się § 22 Statutu); Komisja sprawdza rachunki, analizuje wykonanie przez Zarząd Główny uchwał Walnego Zgromadzenia oraz przynajmniej raz w roku 
przedkłada sprawozdanie Walnemu Zgromadzeniu z przeprowadzonych czynności.

2. Główna Komisja Rewizyjna wyraża swoje stanowisko w formie uchwał, które zapadają zwykłą większością głosów, przy obecności co najmniej połowy członków Komisji, w razie równej liczby głosów rozstrzyga głos Przewodniczącego Komisji".

Za przyjęciem zmiany w głosowaniu jawnym oddano 37 głosów, przeciwko 0 głosów, wstrzymało się 0 członków.

W związku z powyższym Przewodniczący Walnego Zgromadzenia Delegatów PTF stwierdził, iż proponowana zmiana Statutu została przyjęta.

\section{0) dokonać zmiany § 28 poprzez nadaniu mu nowej treści:}

„1. Sąd Koleżeński składa się z pięciu członków oraz 2-ch zastępców i rozpatruje sprawy w składzie co najmniej trzech osób. W skład Sądu Koleżeńskiego wchodzą członkowie Towarzystwa.

2. Sąd Koleżeński rozpatruje sprawy dotyczące naruszeń przez członków Towarzystwa postanowień Statutu PTF, zasad etycznych lub obyczajowych Towarzystwa, naruszeń Statutu PTF przez organy PTF oraz rozstrzyga spory kompetencyjne między organami PTF.

3. Członek PTF występujący przed Sądem Koleżeńskim ma prawo ustanowić pełnomocnika.

4. Sąd Koleżeński wniesione sprawy rozstrzyga w postaci orzeczeń: postanowień lub wyroków.

5. Od orzeczeń Sądu Koleżeńskiego przysługuje prawo wniesienia odwołania do Walnego Zgromadzenia Delegatów PTF w terminie 30 dni od dnia doręczenia orzeczenia uczestnikowi postępowania.

6. Od orzeczeń Sądu Koleżeńskiego stwierdzających naruszenie przez członka postanowień Statutu PTF lub zasad etycznych lub obyczajowych Towarzystwa i orzekających upomnienie, ostrzeżenie lub zawierających wniosek o wykluczenie przez Zarząd Główny PTF z Towarzystwa przysługuje członkowi prawo wniesienia odwołania, zgodnie z § 15 ust. 2 Statutu.

6. Sposób działania Sądu Koleżeńskiego określa Regulamin Sądu Koleżeńskiego PTF przyjęty przez Walne Zgromadzenie PTF".

Za przyjęciem zmiany w głosowaniu jawnym oddano 37 głosów, przeciwko 0 głosów, wstrzymało się 0 członków. 
W związku z powyższym Przewodniczący Walnego Zgromadzenia Delegatów PTF stwierdził, iż proponowana zmiana Statutu została przyjęta.

\section{1) dokonać zmiany $\$ 30$ poprzez nadanie mu nowego brzmienia:}

„1. Władzami Oddziału są:

a) Walne Zebranie Oddziału,

b) Zarząd Oddziału wybierany na cztery lata przez Walne Zebranie Oddziału (w liczbie od 3 do 10 osób, co najmniej: przewodniczący, skarbnik, sekretarz),

c) Komisja Rewizyjna Oddziału wybierana na cztery lata przez Walne Zebranie Oddziału (trzy osoby, w tym przewodniczący).

2. Skład Władz Oddziału może zostać uzupełniony przez Walne Zebranie Oddziału".

Za przyjęciem zmiany w głosowaniu jawnym oddano 37 głosów, przeciwko 0 głosów, wstrzymało się 0 członków.

W związku z powyższym Przewodniczący Walnego Zgromadzenia Delegatów PTF stwierdził, iż proponowana zmiana Statutu została przyjęta.

22) dokonać zmiany $\$ 31 \mathrm{w}$ taki sposób, iż dotychczasową treść oznacza sie jako ustep „1." oraz dodaje się ustepp 2 tak, iż $§ 31$ uzyskuje brzmienie:

„1. Walne Zebranie Oddziału odbywa się co najmniej raz na rok, a zebranie sprawozdawczo-wyborcze raz na cztery lata. Walne Zebranie wysłuchuje sprawozdania Zarządu Oddziału, Komisji Rewizyjnej Oddziału, udziela Zarządowi absolutorium i formułuje zalecenia co do pracy Oddziału na najbliższy rok. Nadzwyczajne Walne Zebranie Oddziału może zostać zwołane na wniosek Zarządu Oddziału, na żądanie 1/4 członków Oddziału albo Komisji Rewizyjnej Oddziału. Zarząd Oddziału zobowiązany jest zwołać takie zebranie $\mathrm{w}$ terminie 1-go miesiąca od wpłynięcia wniosku.

2. Uchwały Walnego Zebrania Oddziału zapadają w pierwszym terminie bezwzględną większością głosów, przy obecności co najmniej połowy członków uprawnionych do głosowania, natomiast $w$ drugim terminie uchwały zapadają zwykłą większością głosów, bez względu na liczbę obecnych, o ile postanowienia Statutu nie stanowią inaczej". 
Za przyjęciem zmiany w głosowaniu jawnym oddano 37 głosów, przeciwko 0 głosów, wstrzymało się 0 członków.

W związku z powyższym Przewodniczący Walnego Zgromadzenia Delegatów PTF stwierdził, iż proponowana zmiana Statutu została przyjęta.

23) dokonać zmiany $\$ 32$ w taki sposób, iż dotychczasowa treść oznacza sie jako ustẹp "1." oraz dodaje się ustẹp 2 tak, iż $§ 32$ uzyskuje brzmienie:

„1. Zarząd Oddziału organizuje zebrania naukowe Oddziału i odczyty publiczne oraz $\mathrm{w}$ odpowiednim zakresie realizuje zadania przewidziane w $\S 8$ Statutu, składając ze swych działań sprawozdania Walnemu Zebraniu Oddziału oraz przesyłając je Zarządowi Głównemu co rok, na miesiąc przed terminem Walnego Zgromadzenia Delegatów.

2. Zebrania Zarządu Oddziału odbywają się w miarę potrzeby, nie rzadziej jednak, niż raz na pół roku, a uchwały Zarządu zapadają zwykłą większością głosów, przy obecności co najmniej połowy członków Zarządu, w razie równej liczby głosów rozstrzyga głos Przewodniczącego Zarządu Oddziału".

Za przyjęciem zmiany w głosowaniu jawnym oddano 37 głosów, przeciwko 0 głosów, wstrzymało się 0 członków.

W związku z powyższym Przewodniczący Walnego Zgromadzenia Delegatów PTF stwierdził, iż proponowana zmiana Statutu została przyjęta.

24) dokonać zmiany $\S 33 \mathrm{w}$ taki sposób, iż dotychczasową treść oznacza się jako ustep "1." oraz dodaje się ustep 2 tak, iż $\$ 33$ uzyskuje brzmienie:

„1. Gospodarka finansowa Oddziału podlega kontroli Komisji Rewizyjnej Oddziału, a nadto Głównej Komisji Rewizyjnej.

2. Komisja Rewizyjna Oddziału wyraża swoje stanowisko w formie uchwał, które zapadają zwykłą większością głosów, przy obecności co najmniej połowy członków Komisji, w razie równej liczny głosów rozstrzyga głos Przewodniczącego Komisji Rewizyjnej Oddziału". 
Za przyjęciem zmiany w głosowaniu jawnym oddano 37 głosów, przeciwko 0 głosów, wstrzymało się 0 członków.

W związku z powyższym Przewodniczący Walnego Zgromadzenia Delegatów PTF stwierdził, iż proponowana zmiana Statutu została przyjęta.

\section{Uchwała w sprawie przyjęcia zmian w statucie}

W związku z dokonanym zmianami Statutu PTF Przewodniczący Walnego Zgromadzenia Delegatów zaproponował by Walne Zgromadzenie Delegatów PTF przyjęło Uchwałę Nr 9/2016 w sprawie przyjęcia zmian w Statucie Polskiego Towarzystwa Filozoficznego. Uchwała w załączeniu do protokołu.

W głosowaniu jawnym za przyjęciem uchwały oddano 37 głosów, przeciwko 0 , wstrzymało się od głosowania 0 . W związku z powyższym Przewodniczący Walnego Zgromadzenia Delegatów PTF stwierdził, iż Walne Zgromadzenie Delegatów Polskiego Towarzystwa Filozoficznego przyjęło Uchwałę Nr 10/2016 w sprawie zmian w Statucie Polskiego Towarzystwa Filozoficznego.

\section{Uchwałą w sprawie przyjęcia tekstu jednolitego}

Przewodniczący Walnego Zgromadzenia Delegatów zaproponował by Walne Zgromadzenie Polskiego Towarzystwa Filozoficznego przyjęło uchwałę w sprawie przyjęcia tekstu jednolitego Statutu, uwzględniającego dokonane zmiany Statutu Polskiego Towarzystwa Filozoficznego. Uchwała w załączeniu do protokołu.

W głosowaniu jawnym za przyjęciem uchwały oddano 37 głosów, przeciwko 0 , wstrzymało się od głosowania 0 . W związku z powyższym Przewodniczący Walnego Zgromadzenia Delegatów PTF stwierdził, iż Walne Zgromadzenie Delegatów Polskiego Towarzystwa Filozoficznego przyjęło Uchwałę Nr 11/2016 w sprawie przyjęcia tekstu jednolitego Statutu Polskiego Towarzystwa Filozoficznego.

XXI.

Prof. B. Markiewicz przedstawiła plan pracy ZG na rok 2016.

Następnie dr M. Gawin przedstawiła plan pracy oddziałów PTF na rok 2016.

Dr hab. M. Zdrenka przedstawił plany związane z wydawaniem „Ruchu Filozoficznego".

Prof. K. Brzechczyn przedstawił sprawozdanie z X Polskiego Zjazdu Filozoficznego. 
W głosowaniu zebrani jednomyślnie przyjęli plan pracy na rok 2016 (Uchwała nr 12/2016).

\section{XXII.}

Prof. B. Markiewicz przedstawiła wniosek o utworzenie oddziału PTF w Białymstoku. Zebrani przyjęli wniosek jednomyślnie (Uchwała nr 13/2016).

\section{XXIII.}

Celina Głogowska zaprezentowała zebranym pismo „Filo-zofuj” i opowiedziała o planach związanych z organizacją Letniej Szkoły Filozoficznej.

Prof. R. Piekarski poprosił o wsparcie PTF dla tej inicjatywy.

XXIV. Dr M. Woźniczka przedstawił apel dotyczący możliwości wprowadzenia filozofii do szkół w Polsce.

S. Kołodziejczyk powiedział, że apele nie koniecznie są dobrym sposobem nacisku na władzę.

Prof. B. Markiewicz zwróciła uwagę, że apel ten musiałby przybrać formę uchwały Walnego Zgromadzenia Delegatów PTF.

Prof. P. Łuków uznał, że może dobrym pomysłem byłoby opracowanie programu nauczania filozofii dla szkół średnich. Zebrani zwrócili uwagę, że programy już są i ważne by było, aby promować nowe inicjatywy.

Prof. B. Markiewicz wspomniała o planach stworzenia atlasu polskiej filozofii.

Dr M. Gawin opowiedziała o pracach, które toczą się w KG OF, nad inną techniką sprawdzania esejów filozoficznych. Uznała, że warto wypracowywać praktyki, którymi następnie można by się dzielić $\mathrm{z}$ resztą społeczeństwa.

K. Michalski zwrócił uwagę na spadek pozycji filozofii i nauk humanistycznych na uczelniach technicznych. Uwagę tę wsparł dr J. Halasz.

XXV. Następnie odbyło się głosowanie, w trakcie którego jednomyślnie przyjęto uchwałę wspierającą apel przedstawiony przez dr Woźniczkę (Uchwała nr 14/2016) oraz również jednomyślnie wyrażono zgodę na to aby był on koordynatorem działań podejmowanych przez PTF na rzecz wprowadzenia filozofii do szkół (Uchwała nr 15/2016).

XVI. Prof. B. Markiewicz odczytała pytania i postulaty napisane przez P. Bielaka. Delegaci uznali, że PTF nie ma możliwości zwalniać młodzieży z zajęć szkolnych, aby ta mogła uczestniczyć w odczytach filozoficznych, podobnie nie może decydować za biblioteki, czy te będą wypoży- 
Protokół z przebiegu Walnego Zgromadzenia Delegatów Sprawozdawczo-Wyborczego 203

czały uczniom książki. Niemniej komitety okręgowe mogą wystawiać uczniom zaświadczenia o uczestnictwie w olimpiadzie i wysłać prośbę do bibliotek, aby te zaświadczenia te uwzględniały.

XXVII. Prof. B. Markiewicz dokonała uroczystego zamknięcia obrad i pożegnała zgromadzonych.

Protokołowała dr Magdalena Gawin 